
\title{
「資源」概念の提案と行為一資源関係の考察 \\ COMPARATIVE STUDY ON OUTDOOR BEHAVIOR OF CHILDREN IN VIETNAMESE RESIDENTIAL AREAS AND KOREAN APARTMENT COMPLEXES \\ Study on concept of environmental resources and behavior-resource relationships

\author{
尹，俊 到*1, 閔 丙 昊*2, 木多道宏*3, 舟橋國 男*4 \\ Jundo YUN, Byungho MIN, Michihiro KITA \\ and Kunio FUNAHASHI
}

ベトナムの居住地と韓国の集合住宅団地における子どもの外部空間行為の比較研究

\begin{abstract}
Two comparable sets of children's neighborhood activities were collected from Vietnam and Korea. This study suggested that the location analysis, although helping describe where each activity most often occurred, was unable to explain why an activity took place in a particular setting but not in other settings. The location-activity relationship analysis also hardly accounted for an activity that occurred across many different settings and a setting where many different activities occurred. This analysis thus focused on environmental resources as an alternative variable. Environmental resources referred to properties, qualities, and elements of neighborhood's sociophysical environment that children explored to use in the instrumental terms for the process of realizing intended activities. The analysis attempted to demonstrate that this alternative variable not only served to explain children's neighborhood activity but also provided conceptual basis to compare children's experiences in neighborhoods of the two different cultures.
\end{abstract}

Keywords: Children, Play, Outdoor Activity, Resources, Residential Areas 子ども、遊び、外部行為、資源、居住地

\section{1. 研究の目的}

本研究は、建筑環境における人間行動が、建築計画者の意図や、 デザインの慣習によって形成された建築環境には適合しないことを検証 するとともに、人間行動の理解や説明を可能とする、より新しい概念を 提示することを目的とする。

利用者の行為と建築計画意図との相違に関する議論は、建築心理学、 環境社会学、環境行動学など、人間の体験に学術的重点を置いた諸般 の研究分野の中で、最も基本的かつ重要な研究課題の一つである ${ }^{1):(1), 3) 。 ~}$ 例えば、建築環境の人間行動規範に関するパターンを提示した

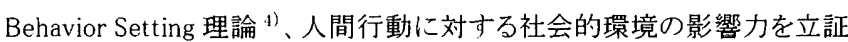
した Social Climate 理論 う)、高齢者の行動と建築環境の関係を説明した

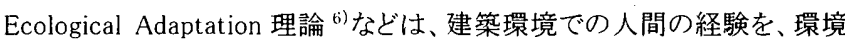
行動論的視点で考察した代表的な成果であると言える。

しかし、近年の研究では、以上のような初期の理論的成果に対し、 人間行動の説明力を付加し、発展させようとする取り組みは少ないと言え る。さらに、実際に人間行動がどのような社会的・環境的要因の影響を 受け、どのような過程で形成されているかについて、理論的構造を提示 することに充分な成果は得られていない。

本研究では、前述の既往の理論を土台とし、人間行動の発現を基本 的に解き明かすための新しい理論構築を試みる。そのための研究対象 として、居住地の外部空間における子どもの行為をとりあげることとした。

\section{2. 既往研究の検討}

子どもの行為に関する研究は、環境行動学、または人間行動学分野 における従来からの核心的な研究テーマであるだけでなく、住居学及び 団地計画研究分野においても重要な位置を占めているう.81。日本でも、 子どもに対する居住地環境の重要性は、環境体験が成長に及ぼす影響、 居住地における遊び場の構造、施設や場所の利用実態などに関する

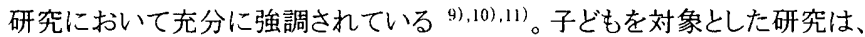
(1)子どもという特別な属性が有している物理的・社会的限界、(2)子どもの 生活の居住環境に対する高い依存度、(3)子どもの行為の特殊性などに 起因して、環境と人間との相互関係の解明や居住環境の計画実務に 重要な貢献を果たしている ${ }^{12)}$ 。

以上のように、子どもの行為に関する研究は、多くの重要な成果を 蓄積しているものの、居住環境におけるどのような要因が子どもの行為に 直接的に影響するのか、また、その要因は、行為の発現過程とどのような 関係にあるのかという課題を系統的に解明した研究は、未だ少ないと いえる。

しかしながら、注目すべき新しい視点が提示されている既往研究も 見られる。これらの研究では、子どもの生活行為が居住環境の物理的 様相や計画的特性ではなく、環境に内在する特定の属性と直接的な 関連があるという考察が提示されている ${ }^{13)}$ 。また、次のような知見も 示されている。子どもの行為は、外部空間の中に存在する事物の柔軟性

\footnotetext{
*1 大阪大学大学院工学研究科建築工学専攻 博士後期課程

*2 亜州大学建築学専攻 教授

*3 大阪大学大学院工学研究科建築工学尃攻 助教授

*4 大阪大学大学院工学研究科建築工学専攻 教授
}

Ph. D. Student, Department of Architectural Engineering, Graduate School of Engineering, Osaka University Prof., Department of Architecture, Ajou University (Korea)

Assoc. Prof., Department of Architectural Engineering, Graduate School of Engineering, Osaka University

Prof., Department of Architectural Engineering, Graduate School of Engineering, Osaka University 
または、操作可能性によって説明され 14)、子どもによる空間利用や認知 は、森、水、花のような自然生態的要素と関連がある ${ }^{15}$ 。さらに、子ども の行為は、地面がどのような特性を持っているのか、外部空間は車と 犯罪から安全であるのか、などに関する子ども自身の評価によって左右 され ${ }^{16)}$ 、一つの場所で行為の領域を確保することができるのか、その 場所が、子どもが遂行しようとする様々な行為を機能的に支援するのか、 といった点に対する子どもの解釈が重要である ${ }^{17) 。 ~}$

本研究では、以上のような機能的属性と関わった既往研究の断片的 な提案などを資源(environmental resources)という概念で体系化する。 資源は、子どもの行為と直接的に関わり、行為の過程において環境から 与えられ、子どもが選択する環境要素であり、行為の観察によって比較 的容易に定義・特定することができる。その定義により、どのような行為が、 どこで、どの程度発生するのかに関する直接的な解明を行うことができる。 また、子どもが特定の行為のために一つの場所を選択するのは、その 場所が行為と関連した資源を有しているかららであり、従って、行為の発生 位置や外部空間の利用の程度は資源の性格と分布を調查することにより 解明できる。行為の多様性は資源の多様性によるもので、子どもの経験 の側面から見れば、資源を多様で豊かに備えた居住地が望ましいと いえる。

本研究では最終的に、資源と行為との関係について、異なる文化に 共通する原理を見いだすことを試みる。文化的背景によって行為に差異 が見られるのは、子どもが探索・活用する資源の性格の相違によるもので あり、資源を行為に関連づける方法に差があるからである。すなわち、資 源という概念を利用することにより、居住環境の比較文化的論議や、行為 の文化的特性に対する論議がより明確になることが期待できる ${ }^{18), 19) 。 ~}$

\section{3. 研究の方法}

本研究は、居住地の外部空間における子どもの行為(以下、「外部 行為」と記す)が外部空間において想定されている使用目的よりむしろ、 環境的な属性である資源によって左右されることを実証し、資源という 理論的な概念を提案しようとするものである。加えて、資源という概念を 用いて、子どもの行為の文化的差異に関寸る具体的な検討が可能で あることを示すため、調査詨象として、ベトナムの「計画されていない」 風土的性向が強い都市居住地と、韓国での「計画的」な集合住宅団地 (15階以上の住棟で構成された分譲集合団地)を選定し、子どもの外部 行為を観察した。

\section{1 調查の対象}

ベトナムの調查対象については、南部のダラット(Da Lat)、ナトゥラング (Nha Trang)、中部のウィニョン(Qui Nhon)、プレーク(Pleiku)、ダナン(Da Nang)、北部のハノイ(Hanoi)、計6都市の居住地を選定した(図 1)。各都 市について基礎資料を検討し、一都市当たり $2 \sim 3$ 地区の調査対象候補 地を選定した後、これら候補地に対する予備調查を通して、各都市 1地区を選定した。選定の基準は研究目的に基づき、(1)既成市街地、 (2)居住の用途が支配的な地域、(3)居住人口の構成に占める子どもの 割合が高く、(4)子どもの外部活動の比較的活発な地域とした。2001 年 2 月 4 日から 2 月 13 日までの間、 6 都市で子どもの外部活動が最も活発 な午後に観察し、行為事例を収集した。

韓国では、ガチョン、ピョンチョン、サンボン、ブンダン、スジ、ヨントンの 首都圈 6 ヶ所の新都市を対象とした(図 1)。各新都市の集合住宅団地の リストを作成した後、新都市毎に、主として高層集合住宅で構成された
典型的な団地を 1 地区ずつ選定した。2001 年 6 月 6 日から 7 月 8 日に おける平日、祝日の午後に観察調査を行い、行為事例を収集した注1)。

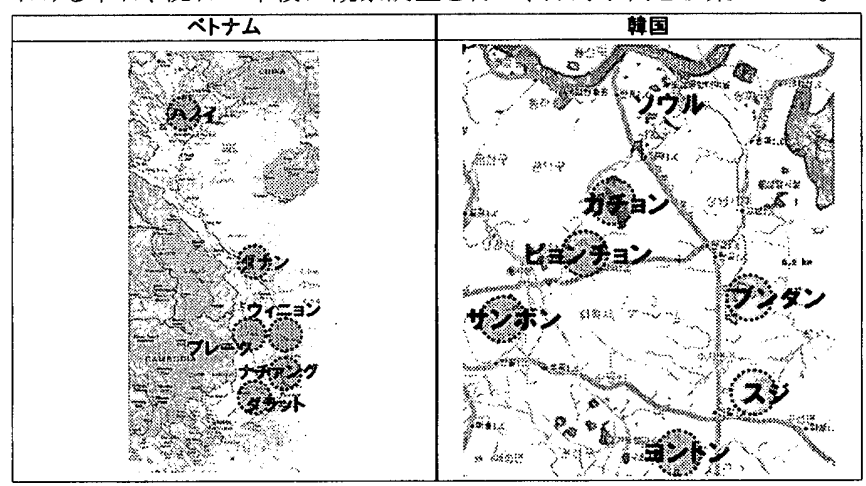

図 1.ベトナムと韓国における調焦対象地

\section{2 調查の方法}

ベトナムと韓国における全調查対象地区の予備調査を行い、(1)(特定 の場所において、複数の子どもに多様な行為が見られる場合)集団のま とまりの特定方法注 2)、(2)一つの行為事例の定義と特定方法注 3)、 (3)観察経路を設定した。観察方法としては、「観察経路法」代 4)を採用し、 街路・団地内通路ならびに、街路・通路からアクセス可能な空地を巡回・ 観察することとした。

観察は2人の調查者によって行い、経路を移動しながら観察される 子どもの行為を、写真及び記録用紙に記録した。プレイロットのように、 限定された空間で多数の行為が同時に発生する場合は、一つの空間に ついて個別に行動プロット図として記録した。

また、一つの行為が発現する要因や発現の過程を把握するため、 行為内容の時閒的変化を連続的に観察し、必要に応じて追跡調查を 行った。一つの行為に連続する、異なる行為までを含めた観察を行い、 行為に関わる社会的・物理的条件などについて、脈絡を考慮した記録を 行うためである。

\section{4. 行為と畦所の関係}

\section{1 行為類型の分析(表 1 )}

行動観察調查の結果、ベトナムの居住地で 129 事例、韓国の集合 住宅団地で 188 事例の行為が収集された。これらを整理するため、既往 研究7).20)を参考に、1 次類型として19 のカテゴリーに分類した後、最終的 に3次類型として 9 の行為類型を得た。行為類型別に、全行為数に占め る割合を比較した結果、ベトナム居住地と韓国集合住宅団地に、いくつ かの重要な相違と類似点を読みとることができる（表 1)。

相違点としては、べトナム居住地では、会話、休息、見物のような静止 型の行為の割合が高いのに対し $(24.0 \%)$ 、韓国団地では、自転車や ローラーブレード乗りなど、移動性の大きい行為が多く見られる(20.2\%)。 また、ボール、遊び道具、乗り物、遊び器具などを、広義の道具として 定義した場合、子どもが使う道具の性格がべトナム居住地と韓国団地で 明白に異なっていることがわかる。べトナムの子どもは、持ち込みが容易 な小型の遊び道具(羽子、玉、ゴム紐など)を使った行為が多いのに対し、 集合住宅団地の子どもは自転車、遊び器具(すべり台、ぶらんこ、うんて い)などの大型で既製の道具に依存する事例の割合が高い。これら道具 を利用した行為について、道具を移動したり、形を変えたり、多様な遊び に利用するといった性質を、能動性と定義すれば、べトナムでの行為は 相対的に能動的であり、韓国は受動的であるといえる。 
一方、類似点については、ボール遊び(球技、単純ボール遊び) と、 道具を使わない身体ゲーム(かくれんぼなど)は、ベトナム $(28.7 \%)$ と韓国 団地(19.1\%)の両地区おいて、一定の割合を占める主要な行為となって いる。また、おもちゃなどの道具を利用する行為が多い点も、類似した 特徴となっており、自転車、遊び器具なども道具に含める場合(ボール 遊びは除く)、こ札らの行為は、べトナムで $31.8 \%$ 、韓国団地で $51.6 \%$ の 高い割合を占めている。

行為の類似性は、集合住宅団地の計画的特性が、子どもの行為に 直接的な影響を及ぼすとは言えない点を示唆している。ベトナムの居住 地と韓国の集合住宅団地の居住環境に著しい差異が見られるにもかか わらず、ボール遊び、ゲーム遊び、道具遊び、自然遊びの行為などは、
物理的環境の相違に関倸なく、共通して発生しているといえる。これらの 行為に現れる差異としては、異なる経済的条件の中で提供される道具の 性質と、これら道具に関連する行為の能動性に限ってあげることが できる。

\section{2 行為の発生位置(表2)}

行為の発生位置もべトナム居住地と韓国団地に類似する様相が見ら れる(表 2)。ベトナムでは道路を利用する行為の割合が高く $(70.5 \%$ )、 同様に韓国の場合も、道路 (道路に連続する駐車場を含む)が最も重要 な行為の場所であると言える(41.5\%)。道路の重要性については、日本や 韓国の集合住宅団地、ヨルダン、インドなどの居住地における子どもの “行為に関する既往研究結果と一致する 1'),21),22),23)。道路は自動車の

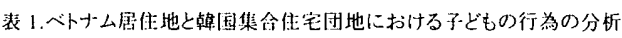

\begin{tabular}{|c|c|c|c|c|c|c|c|c|c|c|}
\hline 行公数型 3 & 行数 & 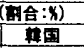 & 行击颣型 2 & 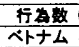 & 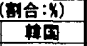 & 行为粼型 1 & \multicolumn{2}{|c|}{ 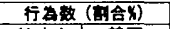 } & 行为颗梨1の内㻤 & 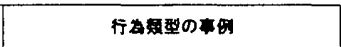 \\
\hline \multirow{4}{*}{$\begin{array}{l}\text { 1.話/静止型 } \\
\text { 行為 }\end{array}$} & \multirow{4}{*}{ (24.0) } & \multirow{4}{*}{$3(6,9)$} & \multirow{2}{*}{ 1.嶉/休鸹 } & \multirow{2}{*}{$14(10.9)$} & \multirow{2}{*}{$8(4.3)$} & & $\mathrm{I}(0.8)$ & \multirow{2}{*}{$\begin{array}{l}7(3.7) \\
1(0.5) \\
\end{array}$} & 他者と会話を寸万行為 & \multirow{2}{*}{ 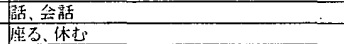 } \\
\hline & & & & & & 2. 体烈 & $13(10.1)$ & & 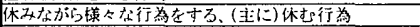 & \\
\hline & & & 徘徊/稓察 & $|7(13.2)|$ & $5(2.7)$ & 3.見物、毁祭 & $2(1.6)$ & & (表に)特定事物队行为を見ること & 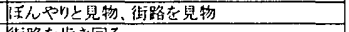 \\
\hline & & & F. & [1, (15.2) & $5(-.+4$ & 4.绯徊 & $15(11.6)$ & $5(2.7)$ & 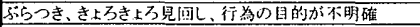 & 街路を监き回了 \\
\hline \multirow[b]{2}{*}{2 ポール遊び } & \multirow[b]{2}{*}{$16(1 \%-4)$} & \multirow[b]{2}{*}{$19(10.1)$} & \multirow[b]{2}{*}{ 秝ー゙ール遊び } & \multirow[b]{2}{*}{$16(12.4)$} & \multirow{2}{*}{$19(10.1)$} & 5゙ボール遊びー梂披 & $4(3.1)$ & $7(3.7)$ & にールホススなよ゙を利肺したスホーーツ類似行為 & サッカー、ハススケットボール \\
\hline & & & & & & 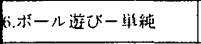 & $12(9.3)$ & $1:(6,4)$ & 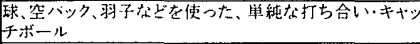 & 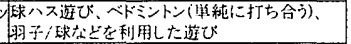 \\
\hline $3 . S^{*}-\Delta$ 遊ひ & $10(7.8)$ & $14(\bar{\pi} .4)$ & 本.ゲーム遊び & $10(\pi .8)$ & $14(7.4)$ & 7.グーム遊び & $10(7.8)$ & $14(\overline{7}, 4)$ & 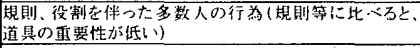 & 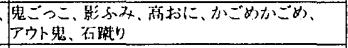 \\
\hline \multirow{2}{*}{ 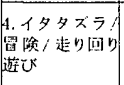 } & \multirow{2}{*}{$18(14.0)$} & \multirow{2}{*}{$15(8.0)$} & \multirow{2}{*}{ 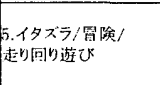 } & \multirow{2}{*}{$18(14.0)$} & \multirow{2}{*}{$\mid 5(8.0)$} & 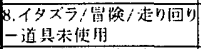 & $15(11.6)$ & $10(5.3)$ & 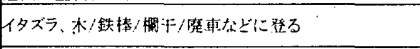 & 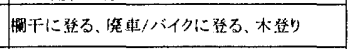 \\
\hline & & & & & & 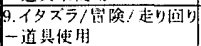 & $3(2.3)$ & $5(2.7)$ & 檤具を使ったイタズラ遊び、晢険型遊び & 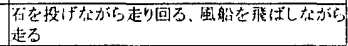 \\
\hline \multirow{4}{*}{ 5. 道具遊U゙ } & \multirow{4}{*}{$39(30.2)$} & \multirow{4}{*}{$31(16.5)$} & \multirow{2}{*}{ 6。道具(遊び用)遊び } & آت & 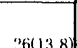 & 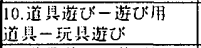 & $16(12.4)$ & $29(11 . \pi)$ & おちもらかをを利用した遊び & 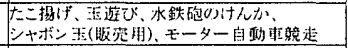 \\
\hline & & & & $-8 \pi-1.11$ & & 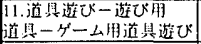 & $1:(9.3)$ & $4(2,1)$ & 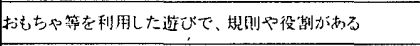 & ままごと、カートト遊び、楮跳び、ジムとも゙ \\
\hline & & & & & $5(2.7)$ & 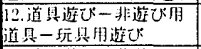 & $i(5.4)$ & $3(1.6)$ & 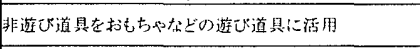 & 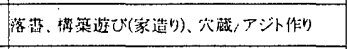 \\
\hline & & & & $11(8.5)$ & . & 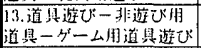 & $4(3.1)$ & $2(1.1)$ & 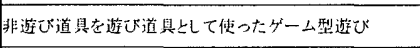 & 限き物投げ \\
\hline 6. 避び器具遊 & & 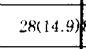 & 8. 遊以“器县遊ひ” & & $28(1.9 .9)$ & 14. 遊び器具遊び & & $28(14.9)$ & 既製の遊び器具を利用した行為 & 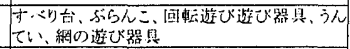 \\
\hline & & & & & & 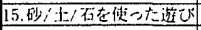 & $5(3.9)$ & $20(10.6)$ & 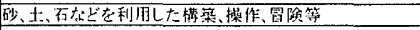 & 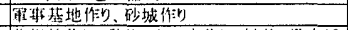 \\
\hline 7. 囷然遊び & $10(7,8)$ & $30(16.0)$ & 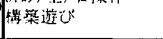 & $10(7.8)$ & $30(16.0)$ & 16.植物/徽物遊凶 & $5(3.9)$ & $10(5.3)$ & 自然物(動物、植物)在利用した遊び & 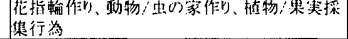 \\
\hline (8. 乘り物遊び & $2(1.6)$ & $38(20.2)$ & 10 乘り物遊び & $2(1,6)$ & $38(20.2)$ & $\begin{array}{l}\text { 17.乘り物遊び } \\
\text { (Wheet Play) }\end{array}$ & $2(1.6)$ & $38(20.2)$ & 白転䔩、ローラープレイド、キッグーート等の乘り物に乘る & 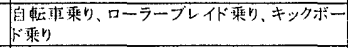 \\
\hline 9.自的行為 & $3(2.3)$ & & 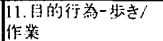 & $3(2.3)$ & & 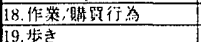 & $3(2.3)$ & & なと見的行為 & 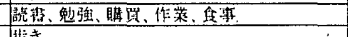 \\
\hline
\end{tabular}

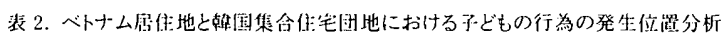

\begin{tabular}{|c|c|c|c|c|c|c|c|c|c|c|}
\hline \multirow{2}{*}{ 埧所颣型 3} & \multirow{2}{*}{ 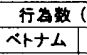 } & \multirow{2}{*}{ 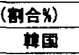 } & \multirow{2}{*}{ 堨所龂型 2} & \multicolumn{2}{|c|}{ 行为数 (腤合X) } & \multirow{2}{*}{ 堨雨数型1 } & \multicolumn{2}{|c|}{ 行为数 (新合X) } & \multirow{2}{*}{ 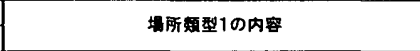 } & \multirow{2}{*}{ 堣所稹型の事因 } \\
\hline & & & & ヘト+ム & H和 & & ヘト+ム & n & & \\
\hline \multirow{4}{*}{ 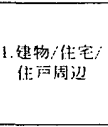 } & \multirow{4}{*}{$29(23.5)$} & \multirow{4}{*}{$13(6.9)$} & \multirow{4}{*}{ 1, 建物/住宅/住: $=10$} & \multirow{4}{*}{$99(29.5)$} & \multirow{4}{*}{$13(6.9)$} & 1.芝罣階段/坄㨁 & $6(4.7)$ & $4(2.1)$ & 建物;住宅仁進入才る階段や颃斜路 & 外部階段、進入階段/佰科路 \\
\hline & & & & & & 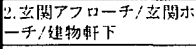 & $15(11.6)$ & $9(4.8)$ & 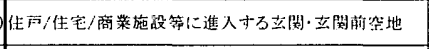 & 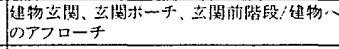 \\
\hline & & & & & & 3.建物; 住宅它庭 & $7(5.4)$ & & 建物及心住宅の前庭 & 家0)庭 \\
\hline & & & & & & 4.旗策施没 & $\mathrm{I}(0.8)$ & & 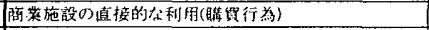 & 文其洁，商侸 \\
\hline \multirow{4}{*}{ 檤路 } & \multirow{4}{*}{$91(70.5)$} & \multirow{4}{*}{$49(26.1$} & \multirow{4}{*}{ 3. 㨁路 } & \multirow{4}{*}{$9 t(70.5)$} & \multirow{4}{*}{$49(26.1)$} & 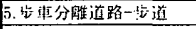 & $29(2+\ldots)$ & $13(6.9)$ & 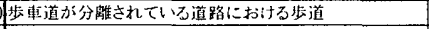 & 发渞 \\
\hline & & & & & & 6.這車分觹道路一本道 & $7(5.4)$ & $16(8.5)$ & 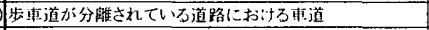 & 本檤 \\
\hline & & & & & & 7. 些䡛隄合道路 & $18(14.0)$ & $3(1.6)$ & 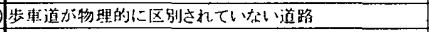 & 拉車湜会道路、細街路 \\
\hline & & & & & & 8.步行看花用㐤路 & $37(28.7)$ & $17(9.0)$ & 步行のみのための道路、局仁地内の緑道 & 㱩㐤、フロムナート \\
\hline 3.河車坦 & & $29(15.4)$ & 3.駐車場 & & $29(15.4)$ & 10.駐望增-車道 & & $27(14,4)$ & 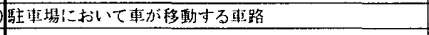 & 駐車场内の旺路 \\
\hline \multirow{6}{*}{ 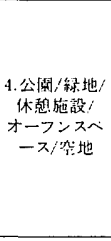 } & \multirow{6}{*}{$9(7.0)$} & \multirow{6}{*}{$20(10,6)$} & $\begin{array}{l}\text { 4.1埸 } \\
\text { オーフンスベース }\end{array}$ & $2(1.6)$ & & $\begin{array}{l}11 \text { 䒧場! } \\
\text { オープンスベース }\end{array}$ & $2(1,6)$ & & 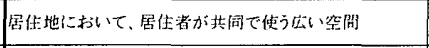 & 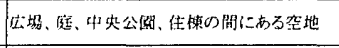 \\
\hline & & & 5.休俧施設/空開 & & $6(3.2)$ & 12 休䓡施設/空問 & & $6(3.2)$ & 住民の休思のたぬのの空閣 & バーゴラバンチ亲どの休息施般 \\
\hline & & & \multirow[b]{2}{*}{ 6. 線地 } & & \multirow[b]{2}{*}{$14(7.4)$} & 13.耓得緑地 & & $11(\overline{5} .9)$ & 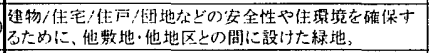 & 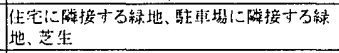 \\
\hline & & & & & & 14. 近绦公激 & & $3(1,6)$ & 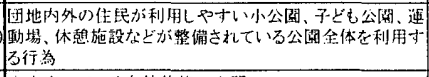 & 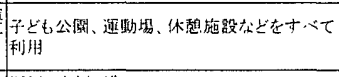 \\
\hline & & & \multirow{2}{*}{ 7.萑地/空き地 } & \multirow{2}{*}{$7(5,4)$} & & 15. 萑地 & $1(0.8)$ & & 本来筀いている自然状悲の空問 & 河川，小川、㴖 \\
\hline & & & & & & 16.空き地 & $6(4.7)$ & & 建物が建てられていない教地 & 空き地、工事現埸 \\
\hline \multirow{2}{*}{ 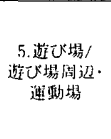 } & . & $77(41.0)$ & $\log _{0}$ & & & 18. 連動施竞 & & $3(1.6)$ & 通動のための施設 & 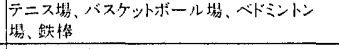 \\
\hline & & & 9.遊区埸 & & $6 \cdot(33.0)$ & 19.遊ひ场游び路县 & & $35(18.6)$ & 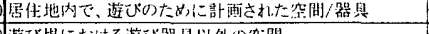 & 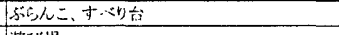 \\
\hline
\end{tabular}

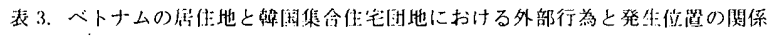

\begin{tabular}{|c|c|c|c|c|c|c|c|c|c|c|c|c|}
\hline \multirow{2}{*}{ 行为绕 3} & \multicolumn{2}{|c|}{ 建物/住宅/住户周讱 } & \multicolumn{2}{|c|}{ 遄路 } & \multicolumn{2}{|c|}{ 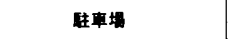 } & \multicolumn{2}{|c|}{ 公園/倲地/休息空间 } & \multicolumn{2}{|c|}{ 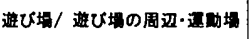 } & \multicolumn{2}{|c|}{ 合 t $(\$)$} \\
\hline & ヘトナム & n⿴囗十 & ベトナム & H国 & ヘトナムム & n国 & ヘトナム & 10国 & ヘトナム & 10国 & ペトナム & n国 \\
\hline 話/觧止型行為 & $9(\tau .0)$ & $1(0.5)$ & $20(15.5)$ & $5(1.7)$ & & $1(0 . \bar{n})$ & $2(1.6)$ & $2(1.1)$ & & $4(2.1)$ & $31(24.0)$ & $13(6.9)$ \\
\hline ボール遊び & $1(0.8)$ & & $12(9.3)$ & $2(1.1)$ & & $5(2.7)$ & $3(2.3)$ & $3(1.6)$ & & $9(4.8)$ & $16(1: .4)$ & $19(10.1)$ \\
\hline 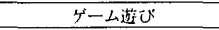 & $1(0.8)$ & & $9(\pi, 0)$ & & & $2(1.1)$ & & $1(0.5)$ & & $11(5.9)$ & $10(7.8)$ & $14(7.4)$ \\
\hline 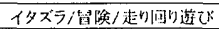 & $3(2.3)$ & $2(1.1)$ & $15(11.6)$ & $8(4.3)$ & & & & $2(1.1)$ & & $3(1,6)$ & $18(14.0)$ & $15(x, 0)$ \\
\hline 㨁其遊び & $11(8.5)$ & $9(1.8)$ & $26(20.2)$ & $10(5.3)$ & & $4(\div .1)$ & $2(1.6)$ & $3(1.6)$ & & $5(2.7)$ & $39(30.2)$ & $31(16.5)$ \\
\hline 遊已器县利湖行為 & & & & & & & & & & $28(14.9)$ & & $28(1.1 .9)$ \\
\hline 自然遊心 & $3(2.3)$ & & $5(3.4)$ & $3(1.6)$ & & $2(1.1)$ & $2(1.6)$ & $9(4.8)$ & & $16(x .5)$ & $10(7.8)$ & $30(16.0)$ \\
\hline 乗り物遊U（Wheel Play) & & $1(0.5)$ & $2(1.6)$ & $21(11.2)$ & & $15(R .0)$ & & & & $1(0.5)$ & $2(1.6)$ & $3 \times(20.2)$ \\
\hline 令部 $(q)$ & $29(2 . .5)$ & $13(6.9)$ & $91(70.5)$ & $49(26.1)$ & & $29(15.4)$ & $9(7,0)$ & $20(10.6)$ & & $\pi \pi(41.0)$ & $129(100)$ & $18 K(100)$ \\
\hline
\end{tabular}


通行による危険性など、否定的な要素があるが、平らな地面、広い空間 などの性質を有するため、早い移動や遊びの変化などが可能であり、 異なる地域との動線や知覚的連結性の点からも、子どもの遊びにとって 有利な特質を備えていると考えられる。

また、主として独立住宅で構成されるべトナムの居住地は、玄関ポー チや前庭など、建物出入口周囲の多様な空間の利用が比較的多い $(22.5 \%)_{0}$ 一一方、韓国団地の場合は、ベトナム居住地ではほとんど見られ ない子どもの遊び場 (及び周辺の空間) と運動場 $(41.0 \%)$ が多く、他に 公園、緑地、休数場所(10.6\%)などの利用が高い割合を占めている。

全体的に遊び場や運動場などの“計画的な遊び空間(designated play areas)'が多く利用されているものの、駐車場を含んだ道路の方が利用の 割合が高く、その重要性が確認できる。

\section{3 行為之発生位置の関係(表3)}

ベトナムの場合は、多様な行為が特定の場所類型に偏る傾向があり （道路 70.5\%、玄関アプローチや庭 17.0\%)、行為類型と場所類型には 有意な相関を見いだすことはできない（ $\left.\chi^{2}=15.07 、 \mathrm{df}=14 、 \mathrm{p}>0.05\right) 。$

一方、韓国の場合は、行為類型と場所類型に有意な相関が見られる (遊び器具利用を除く 160 事例による検定: $\chi^{2}=98.75 、 \mathrm{df}=28 、 \mathrm{p}<0.001$ )。 遊び場では、球技や単純ボール遊び、グーム遊び、自然遊びなどが多く、 駐車場では球技やボール遊び、自転車乗りなどの割合が高くなって いる。

しかし、ここでも球技や単純ボール遊びが、駐車場、遊び場、運動場 などの多様な場所に生じる現象、会話などの静止型行為が道路で多く 発生する現象、おもちゃなどの道具遊びが建物周辺、道路、遊び場など で生じる現象などを、具体的かつ個別に説明することは難しい。韓国の 集合住宅団地でも、道路が多様な行為を包容する実態を考慮すれば、 単純に行為の発生位置や、外部空間の計画的空間区画が子どもの行為 と直接的な関係があると見ることはできない。

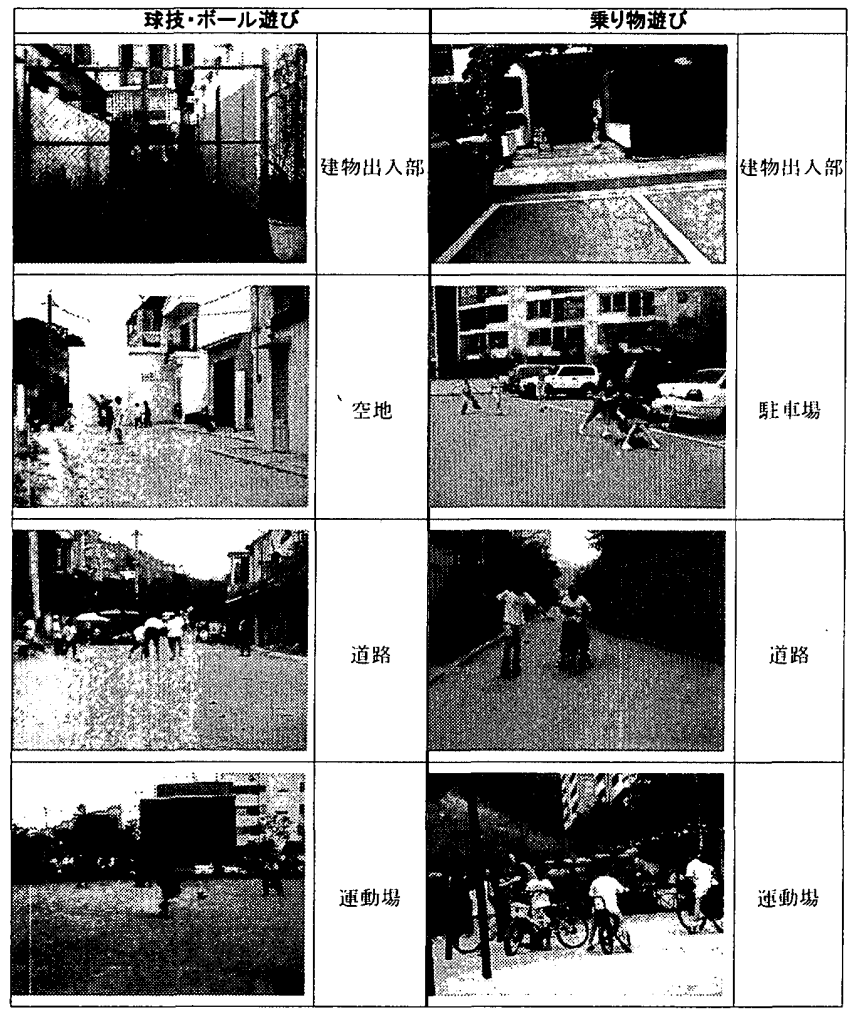

図 2.つの行為が多椂な㤼所で発牛する小例
ここで、特に重要な点は、ベトナム、韓国とも、一つの行為が様々な 位置で発生することであり、これらを、場所類型や計画的空間区分とは 関係なく、様々な場所で発生する行為 (Location-independent activity and activity free from space planning) と言うことができる。さらに、ベトナム と韓国における一つの場所類型で、性格の異なる様々な行為が生じる 現象、寸なわち、居住地の外部空間が “多重行為の場所(multi-activity place)'の役割を有しているという点が住目される。

\section{4 多くの場所で発生する行為}

行為類型毎に、主に行為の発生する位置を整理した上で、その現象 の説明を試みた(図 2)。例えば、ボール遊びが、空地、道路、広場、運動 場などで観察される現象は、これらの場所が球技やボール遊びの行為を 支援する特定の環境的属性(例: 一定の規模の開かれた空間、平らな 地面、遊び領域の確保の可能性など)を共有することで説明される。また 自転車乗りの場合も、道路、駐車場、建物出入部などで発生しており、 これらの場所が自転車乗りに要求される特定の環境的特質(例: 一定の 規模の開かれた空間、平らな地面、車の通行が少ない空間、特定の時 間における車の通行の少なさ)を子どもに提供していると考えられる。つま り、一つの行為は、その行為が必要とする特定の環境の属性または、機 能的な性質が提供されるどのような空間でも発生していることが分かる。 これは、子どもの行為経験が、位置また計画的空間区画よりむしろ、行為 と直接に関連づけられた“環境の機能的な属性(functional properties of environment)'によって説明されることを意味しており、既往の研究 1:1 とも整合する。

\section{5 多様な行為が発生する場所}

一つの場所類型で様々な異なる行為が発生する現象は以下のように 説明できる。特に、道路は多様な行為が観察される代表的な場所で、 ボール遊び、各種の身体ゲーム遊び、自転車乗り、道具遊び、走り回り、 ゲーム遊び、休息、徘䧃など、子どものほぼ全ての行為が行われている

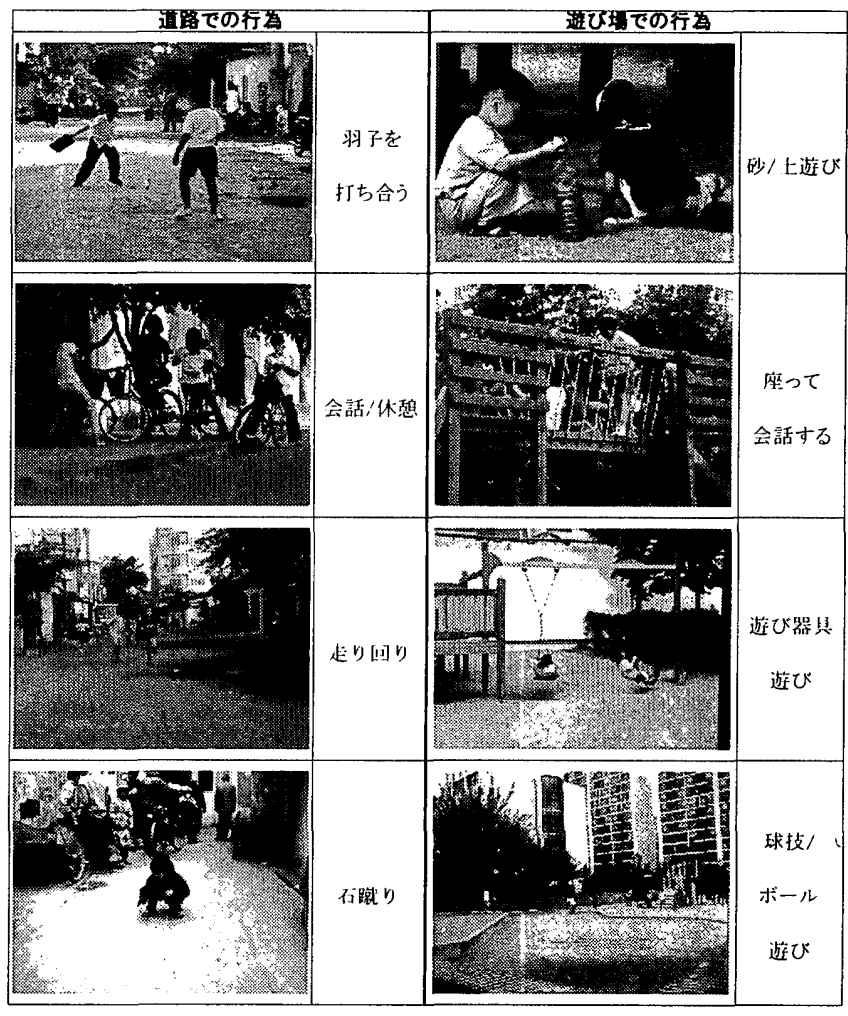

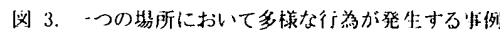


(図 3)。子どもの視点で見れば、道路はこれらの行為を支援する多様な 環境の属性を保有しており、例えば、空間的・知覚的連結性社 5)、地面の 特性、一定の規模を有する平らな空間、領域確保の可能性などは他の 外部空間が提供できない特別な属性であるといえる。

遊び場でも、遊び器具の利用の他、砂・土遊び、会話、ゲーム、ボール 遊び、休息など多様な行為が観察される(図 3)。遊び場が多重行為の場 所(multi-activity place)として利用されるのは、遊び器具、砂、日陰、ベン チ、遊び領域、遊び仲間などのような、多様な機能的属性や環境の特性 に起因している。

\section{5. 凘源の概念及び子どもの行為との関係 5.1 资源の概念}

ベトナム居住地と韓国集合住宅団地における子どもの行為の分析 結果より、子どもの行為は、特定の外部空間における諸要因や環境的性 質が、自分がしようとする行為をどのように支援してくれるかの問題、すな
わち、その行為之関わる外部空間の物理的・社会的環境の属性や特質 (qualities)に影響を受けることがわかる。外部空間は、想定された“本来” の用途に関わらず、特定の物理的・社会的属性を有しており、その属性 の機能的な支援により、行為が誘導されると考えることができる。

例えば、休息の行為については、ベトナム居住地と韓国集合住宅団地 のいずれにおいても、話し相手としての友達、座ることができる椅子、 椅子の代用の物理的要素(階段など)、陰などの環境的属性が行為の 発現のために採択されている。ボール遊びのためには、球、遊び仲間及 び友達、一定の規模の空間、平らな地面などが必要とされ、また、石蹴り は同様の属性の他に、ゲームの規則、地面に描かれた線などが加わる。

このような環境的属性や要素は、行為に直接的かつ機能的 (instrumental)役割を果たす点、さらに行為が発現する過程で選択される 素材(raw materials)であるという点で、行為の資源(resources)と言うことが できる。

以上のように、資源は社会的・物理的な環境の属性であり、行為に

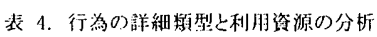

\begin{tabular}{|c|c|c|c|c|}
\hline \multicolumn{2}{|c|}{ 行為類型-大分類 } & \multirow{3}{*}{\begin{tabular}{|l|} 
行為類型-中分類 \\
静止型会䟯 \\
\end{tabular}} & \multirow{2}{*}{\begin{tabular}{|l|}
\multicolumn{2}{|c|}{ 行為類型-小分類 } \\
立って話寸 \\
\end{tabular}} & \multirow{2}{*}{ 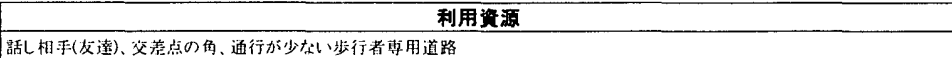 } \\
\hline \multirow{9}{*}{$\begin{array}{l}\text { 話; 静.此型行 } \\
\text { 為 }\end{array}$} & \multirow{6}{*}{$\begin{array}{l}\text { 会話; } \\
\text { 休息 }\end{array}$} & & & \\
\hline & & & 座って話す & 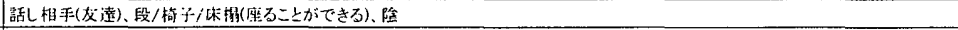 \\
\hline & & \multirow{2}{*}{ 移動型会話 } & 移動したが話す & 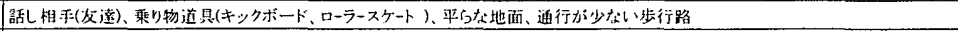 \\
\hline & & & 動きな゙゙ら話す & 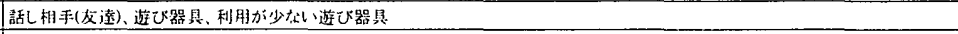 \\
\hline & & \multirow{2}{*}{ 静此型你息 } & 堅のて休思 & 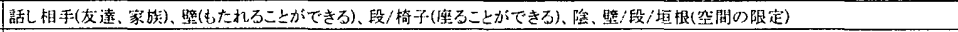 \\
\hline & & & 立って休臨 & 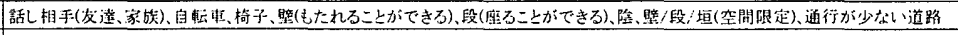 \\
\hline & \multirow{3}{*}{ 俳徊; } & \multirow{2}{*}{ 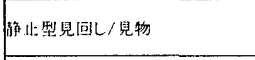 } & 立って見国儿/見物 & 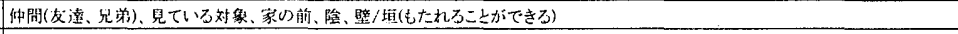 \\
\hline & & & 座って見回し/見物 & 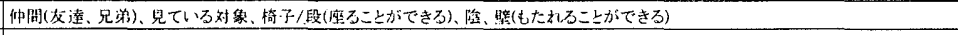 \\
\hline & & 胗動型俳䧃/胃物 & 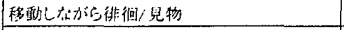 & 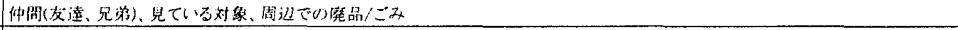 \\
\hline \multirow{6}{*}{ ボール遊じ } & \multirow{4}{*}{$\begin{array}{l}\text { ボール } \\
\text { 遊び }\end{array}$} & \multirow{3}{*}{ 垏純ボール遊び } & 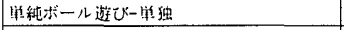 & 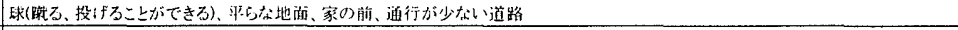 \\
\hline & & & 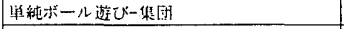 & 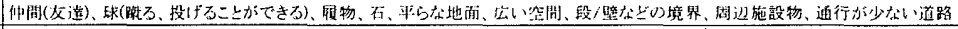 \\
\hline & & & 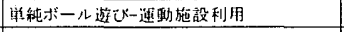 & 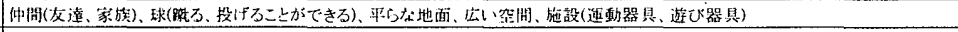 \\
\hline & & 道貝利用ボール，球技遊び & $\begin{array}{l}\text { 道具利用ボール遊び球ホボール以外の他の } \\
\text { 道具) }\end{array}$ & 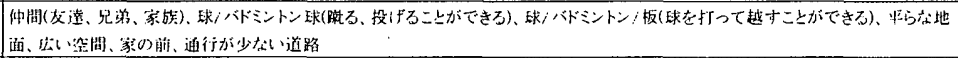 \\
\hline & \multirow{2}{*}{$\begin{array}{l}\text { 球技 } \\
\text { スホーツ }\end{array}$} & \multirow{2}{*}{ スホホーツーボール/的技 遊び } & スボーツーボール遊び(連動施設未利用) & 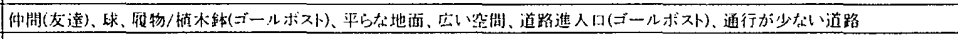 \\
\hline & & & スボーツーボール遊じ(避動施設利用) & 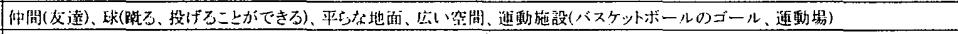 \\
\hline \multirow{3}{*}{\multicolumn{2}{|c|}{ ゲーム遊び }} & \multirow{2}{*}{ 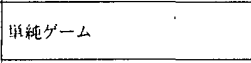 } & 単純身体占一ム & 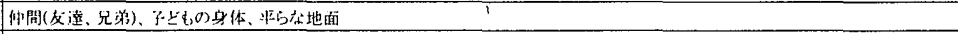 \\
\hline & & & 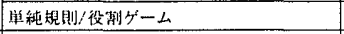 & 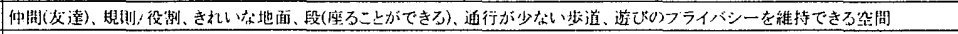 \\
\hline & & 陵筑物/施設利用ゲーム & 潭鹤物/施没利用ゲーム & 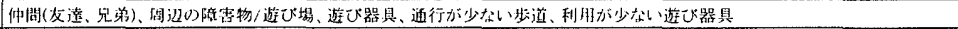 \\
\hline \multirow{5}{*}{ 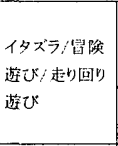 } & \multirow{3}{*}{$\begin{array}{l}\text { 起国り- } \\
1 タ x^{\prime} 5\end{array}$} & \multirow{2}{*}{ 道純イタズラ/起り国り } & 里純イタズラ & 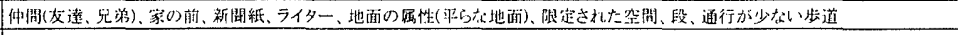 \\
\hline & & & 违り(鱼何 & 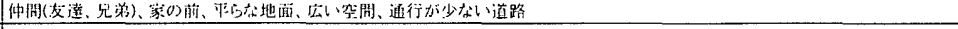 \\
\hline & & 多ズラ/起甸回り一道县使用 & イタスラーー道县利朋 & 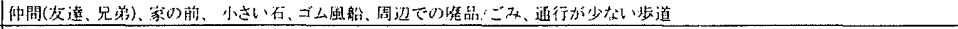 \\
\hline & \multirow{2}{*}{ 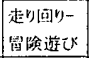 } & 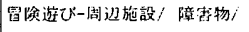 & 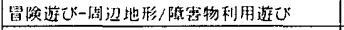 & 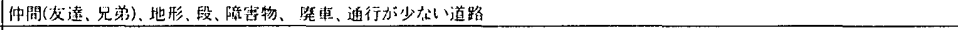 \\
\hline & & 梅造物利用 & 冒険游び-人工㭗造物利朋 & 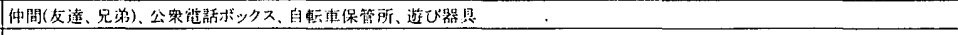 \\
\hline & & & 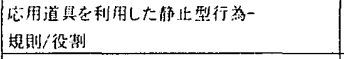 & 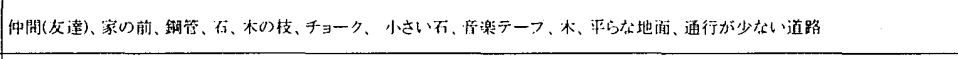 \\
\hline & & & 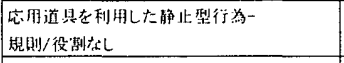 & 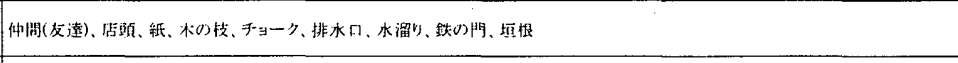 \\
\hline & $\begin{array}{l}\text { 非遊び用 } \\
\text { 道具 }\end{array}$ & 空用随县 & 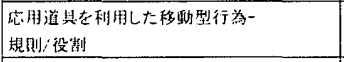 & 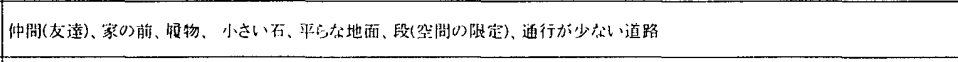 \\
\hline & & & $\begin{array}{l}\text { 応用道具を利用した移郋型行為一 } \\
\text { 規即/役制大机 }\end{array}$ & 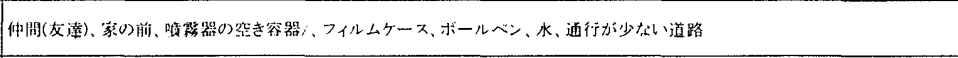 \\
\hline & & & 目的道具一自作淔具を利用した静止塰遊び & 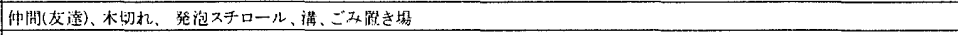 \\
\hline 植具遊的 & & 国的㨁畟一国作品 & 目的道县一自作道息を利用した移動型遊び & 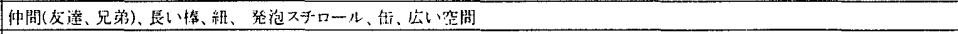 \\
\hline & & & 目的道具一既榷淔具を利朋した静止型 & 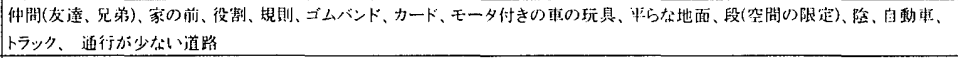 \\
\hline & 遊ひ用 & 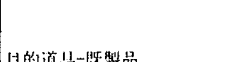 & 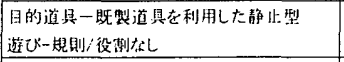 & 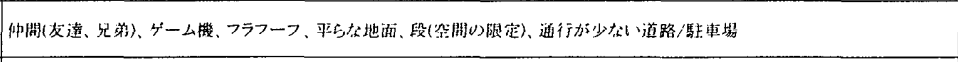 \\
\hline & & & 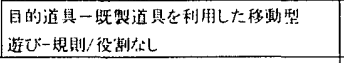 & 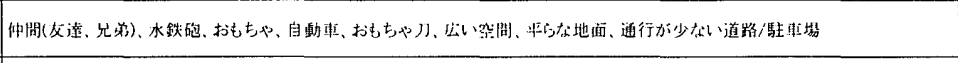 \\
\hline 遊㐱器滕利朋 & & & & 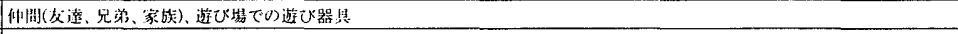 \\
\hline & & 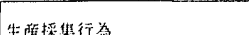 & 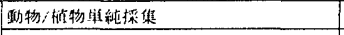 & 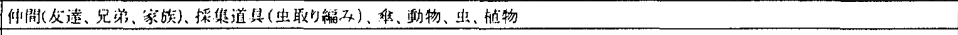 \\
\hline & & 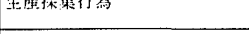 & 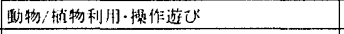 & 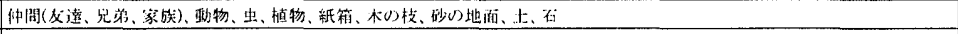 \\
\hline 自然遊び & & 櫵染行為 & 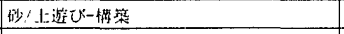 & 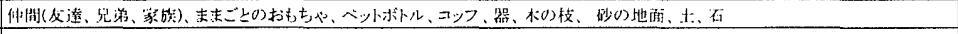 \\
\hline & & 继伤衍为 & 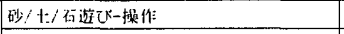 & 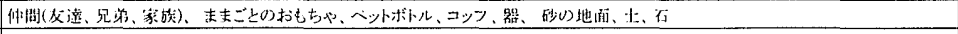 \\
\hline & & 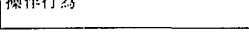 & 水遊U゙ & 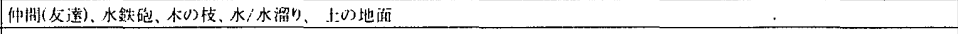 \\
\hline & & & 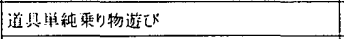 & 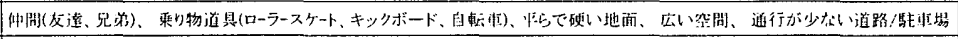 \\
\hline 乗り物遊び & & & 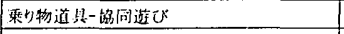 & 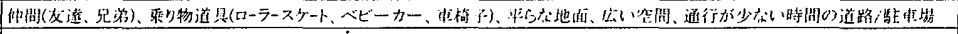 \\
\hline & & & 乘物道县一䢂争遊び & 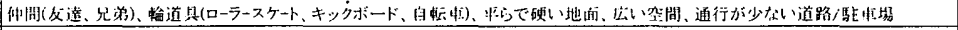 \\
\hline 目的行为 & & & 睡噴 & 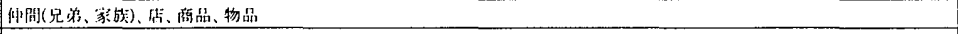 \\
\hline 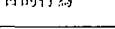 & & & 食事 & 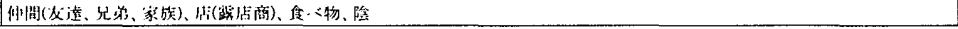 \\
\hline
\end{tabular}


使われる道具、状況などを含む包括的な概念である。これらの資源は、 その性質により、次の 4 タイプに分類することができる。(1)社会的な資源 は行為を一緒に行う仲間、行為に関わる興味や目的を共有する友達を 含む。(2)物理的な資源は、空間的性質(空間の規模など)、物理的要素 (objects and elements)、地面の属性など、物理的環境が有する特性を 指す。また、(3)道具的資源は、子どもによって持ち込まれる道具 (brought-in resources)として、社会的・物理的環境要素に加えられるもの を言う。さらに、(4)状況的資源は、行為と関連つけりれた状況、すなわち、 妨害、危険など、行為の断絶や統制に関わる空間的、時間的、社会的 機会や条件を意味する。

\section{2 利用资源の分析}

ベトナムと韓国で得た行為事例について、子どもの遊びの環境を構成 し、あるいは直接的に利用された資源を特定し、行為類型每に資源の 特性を分析した結果、以下のような知見を得た。

第1に、資源は行為を理解する重要な手段である。どのような資源が どのような行為に関連づけられるかを分析することで、行為をより本質的 に理解し、類型化することが可能となる。表 4 は行為別に資源を特定した
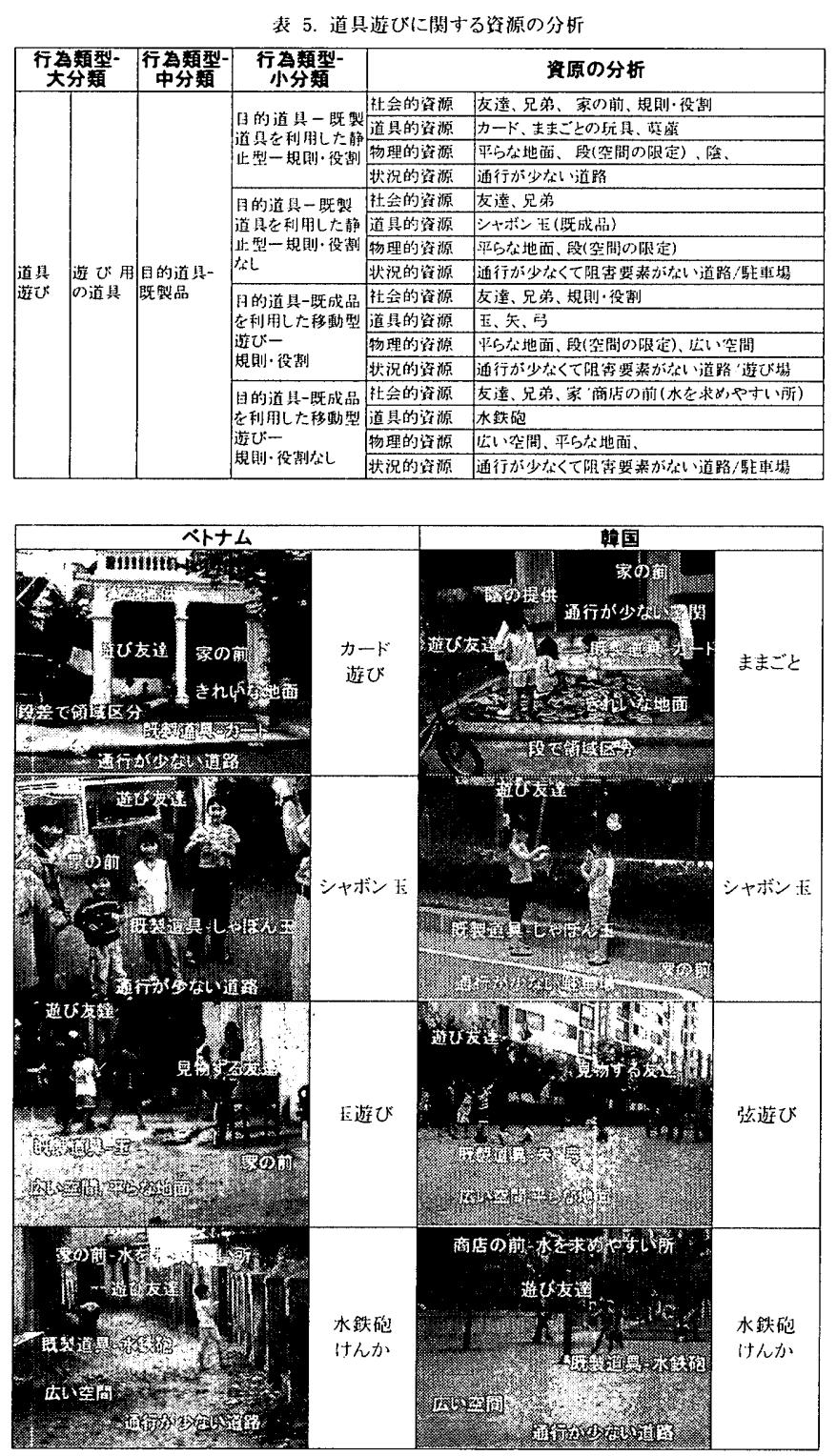

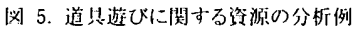

後、各行為に使われた主要な資源によって、行為を詳細に再分類したも のである。以上の分析によって、ベトナムと韓国における子どもの外部 行為を、47の類型に細分化することができた。

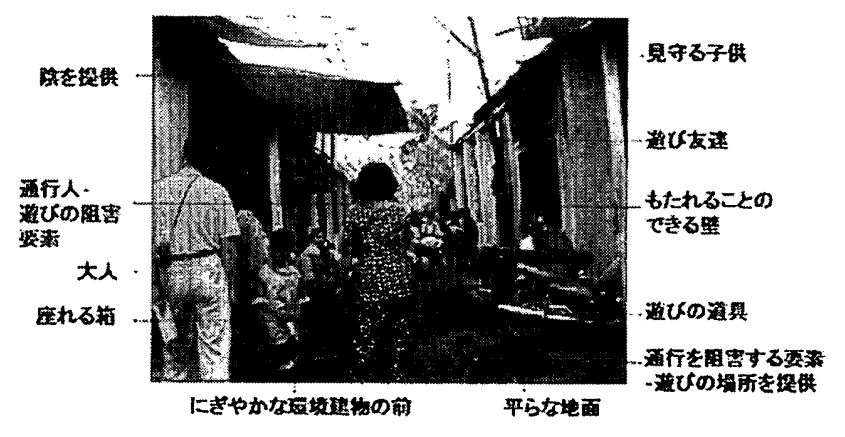

图 4. 资源分析の例

表 6. 自然遊びに関する资游の分析

\begin{tabular}{|c|c|c|c|c|}
\hline 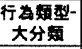 & $\begin{array}{r}\text { 行为類型- } \\
\text { 中分数 }\end{array}$ & 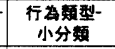 & & 筫原の分析 \\
\hline \multirow{15}{*}{ 自然遊び } & \multirow{6}{*}{$\mid$} & \multirow{3}{*}{$\mid \begin{array}{l}\text { 動物/植物 } \\
\text { 紫純採集 }\end{array}$} & 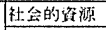 & 发诖、兄弟、家㑟 \\
\hline & & & 道具的资源 & トンボ取りの)網、乘(既成品) \\
\hline & & & 物理的资源 & 兓物、虫、植物 \\
\hline & & \multirow{3}{*}{$\begin{array}{l}\text { 動物/㭪物利 } \\
\text { 用操作遊U }\end{array}$} & 杜会的瓷溍 & 发逹、兄弟、家腊 \\
\hline & & & 道具的虹源 & 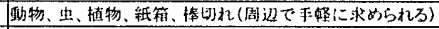 \\
\hline & & & 物理的染㷧 & 砂地，... 石 \\
\hline & \multirow{3}{*}{ 腩箖行為 } & \multirow{3}{*}{ 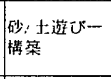 } & 柆会的资源 & 发洼、尣弟、家族 \\
\hline & & & 道县的客源 & 来まご上遊びの玩具、ベットホトル、コッフ、器、溱切れ、 \\
\hline & & & 物理的富源 & 砥地。土、石 \\
\hline & \multirow{6}{*}{ 摸作行為 } & \multirow{3}{*}{ 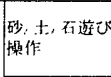 } & 社会的瓷源 & 发迬、尣弟、家㾌 \\
\hline & & & 道具的得源 & 吏まご遊ひの抗思、へットホトル、コッフ、器 \\
\hline & & & 物理的资源 & 砂地、士、石 \\
\hline & & \multirow{3}{*}{ 水遊ひ } & 社全的谯源 & 这迬 \\
\hline & & & 道具的经源 & 水鉄鴙、撩切丸 \\
\hline & & & 物理的埩游 & 小川/办溜的/满 水道 \\
\hline
\end{tabular}

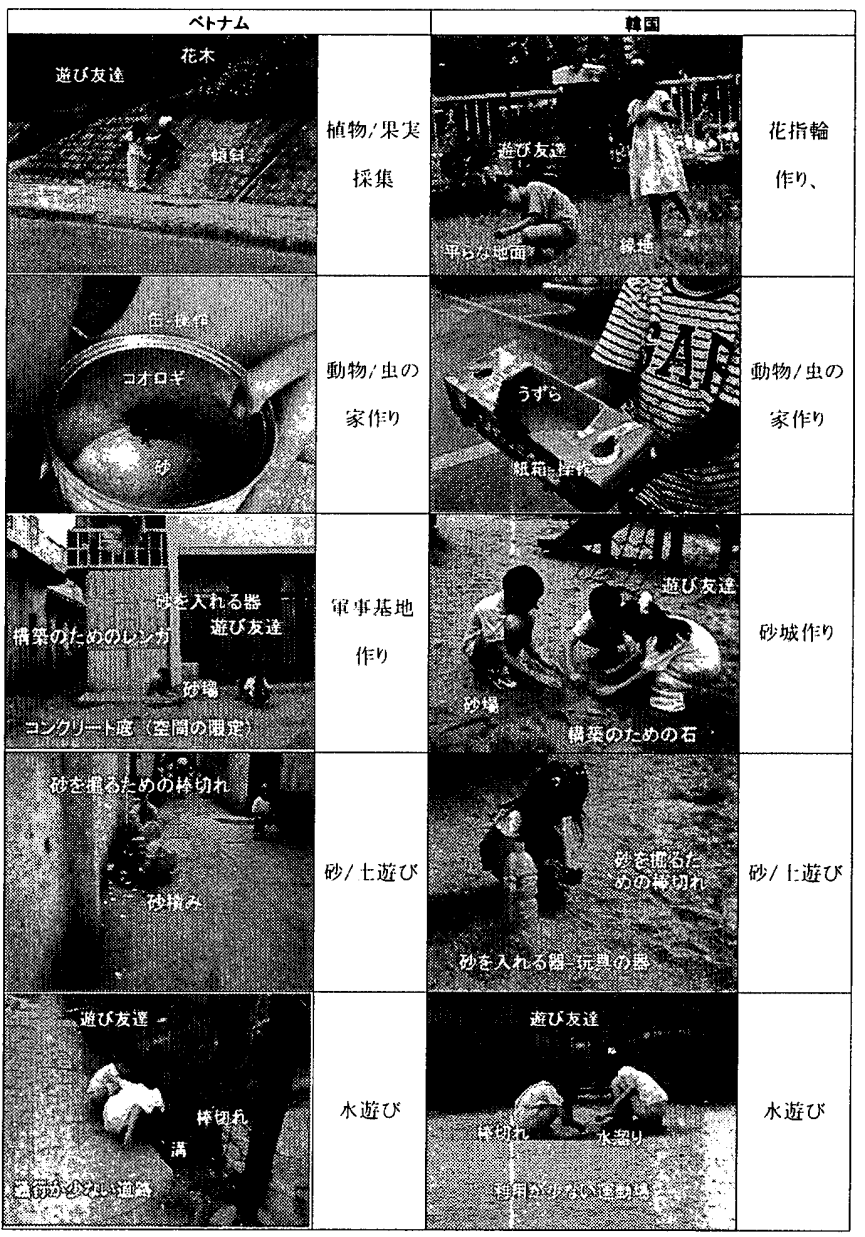

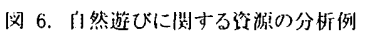


第2に、子どもは自分の行為のために、与えられた環境から非常に 多様な資源を利用していることがわかる。資源は根本的に、道路、遊び 場などのような計画的空間区画とは無関係に、子どもが意図する行為の 内容によって定義される壮6)。行為要求や意図によって必要な資源が 定義されれば、この資源を有する、最も近接した環境を見つけて利用 することになる(例: 表 4 「移動型徘䧃」行為など)。

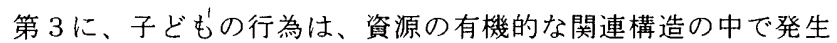
しており、主要な資源の性質が変わ机ば、行為の性質も変化する。 例えば、子どもの集団による細街路での石踔りの事例を検討する 場合、街路における一定の規模の空間、バイクなどを利用した遮蔽 領域の確保、通行など障害要素の排除、遊び友達、地面の特性、 街路の壁などが主要な資源として利用されている(図 4)。子どもの 行為では、これらの社会的、物理的、道具的、状況的資源が特に 重要であり、特定の資源の性質が変化する場合、行為の発生自体が 抑制される、あるいは、行為の性質が大きく変わる場合がある（例： 図 4 の事例において、歩行者やバイクの通行状況が変わる、遊び 友達がいなくなる場合など）。

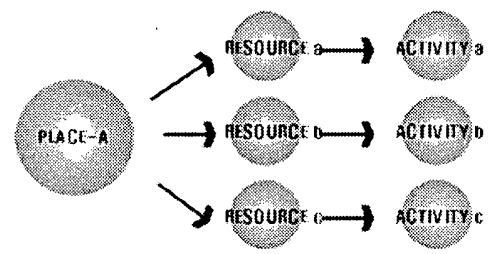

图 7.一つの場所における多梯な凟源と行為の關倸

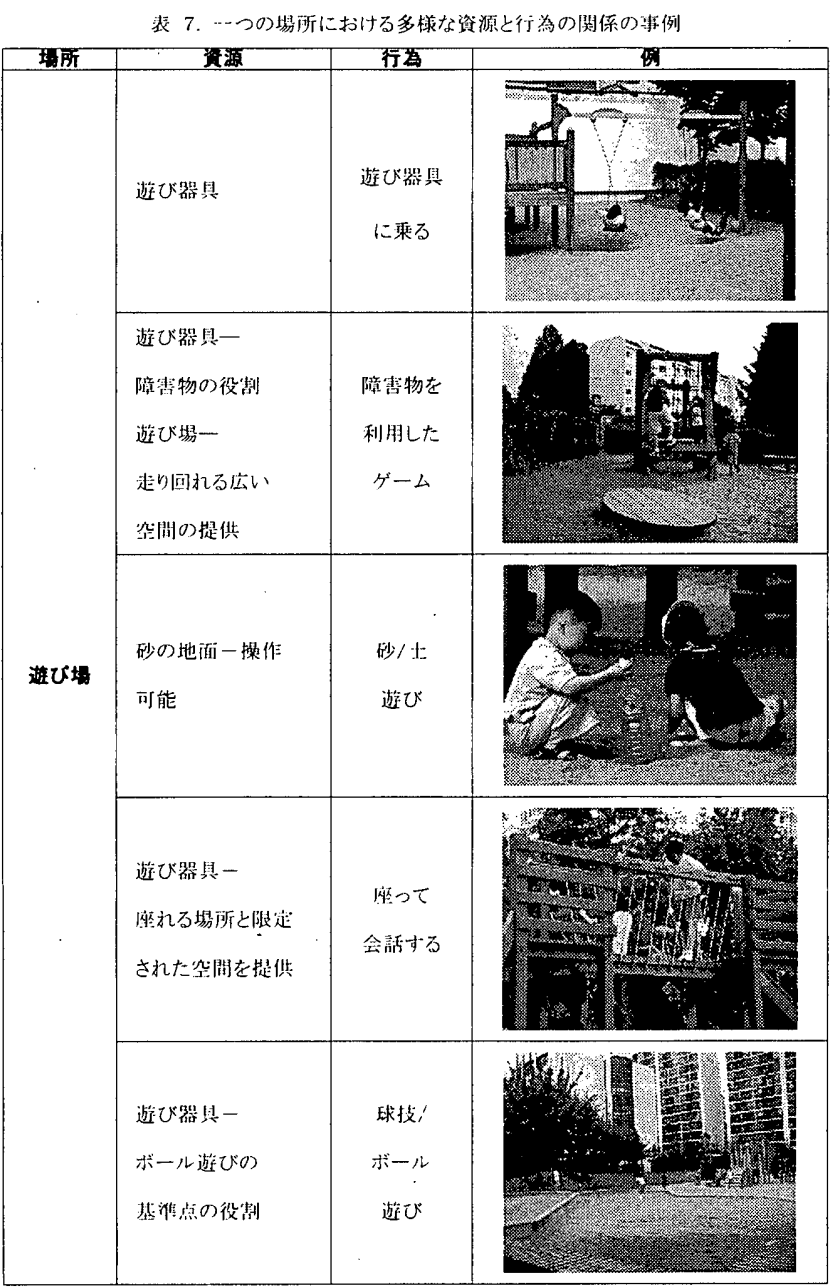

第4に、行為の比較文化的分析において、資源の分析は重要な知見 を提供する場合がある。例えば、異文化間における行為の類似性は、 二つの文化環境で使われる資源が類似していることに起因し(表5、6)、 逆に、行為の文化的差異は、資源の性質の差異または、資源の提供の 可能性の差で説明される。べトナム居住地と韓国集合住宅団地において、 子どもの行為に見られる類似点と差異は、居住地や外部空間における 理論的計画性の有無よりむしろ、居住地の物理的・社会的環境において 子どもが取得する資源の性質によって決まるのである。

ある外部空間が特定の目的に活用されるのは、子どもがその空間に おいて行為目的と関わる特定の資源を知覚寸ることによる。つまり、行為 は子どもが一つの場所で見つけ出す資源の性格によって左右されると 言える。このように、行為に対する居住環境の影響が、資源の媒介的な 役割を通じて成立するという論理に依拠すれば、“多重行為の場所’に 関する現象は容易に説明される。すなわち、一つの場所において多くの 行為が発生するのは、その場所に内包されている資源の多様性に起因 し(図 7、表7)、また、一つの行為が多くの外部空間で発見されるのは、 様々な空間がその行為の発現に関わった特定の資源を共有することに 因る(図 8、表 8)。従って、居住地で多様な子どもの行為を誘導するため に、必ずしも多様な外部空間を提供する必要はなく、むしろ資源の多様 性の確保がより重要な課題となる。

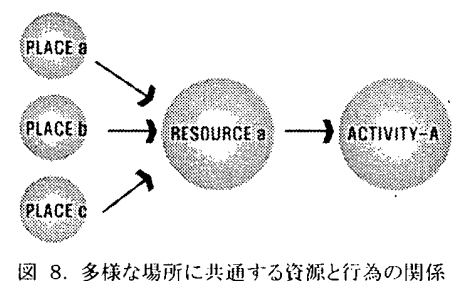

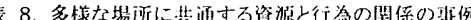

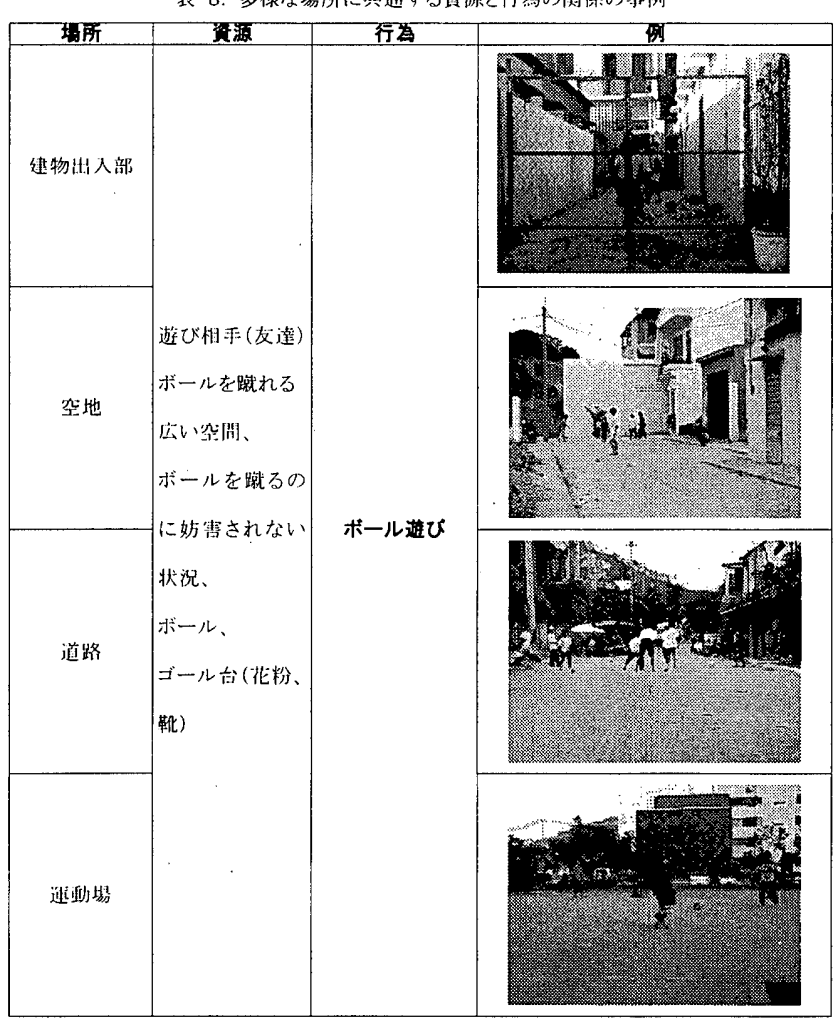




\section{6. 考察}

本研究では、資源(resources)の概念を提案し、資源の概念を用いて 行為の発現のしくみを説明しようと試みた。その結果を以下にまとめる。

\section{1 资源の概念と特性}

行為は、その発生に直接的に関わる環境属性により定義することがで きる。例えば、自転車乗りの行為は、自転車、一定の規模の空間、地面 の物理的な性質、遊び仲間、車の通行による妨害などに関わる環境的 資源の提供によって生じる。子どもは、自分が意図する行為に必要な 資源を備えた環境を探索する。従って、行為は環境自体の物理的性格 ではなく、子どもが環境から搜し出す資源の性質に影響されると言える。

\section{2 資源による子亡゙もの外部行為の分析}

居住地における多くの外部空間が、同じ資源を共有する場合、これら の外部空間は一つの行為を誘導するものであり、逆に、一つの外部空間 が多様な資源を保有すれば、その空間で子どもの多様な行為体験を 期待することができる。

子どもの行為と関連づけられた資源の性質に着目すると、ベトナムの 場合は、持ち運んだり、加工するといった、子ども自身による操作性の 高い資源の利用が多く、能動的な行為との関連が見られた。韓国では、 固定的で操作の可能性の低い資源の利用が多く、相対的に受動的な 行為が見られた。

子どもは多様な行為要求を持っており、この要求を満たすために、 与えられた環境から資源を探索し、遊びに必要なものを構築する。また、 子どもは、自分の行為に必要とする資源を備えた外部空間を選び、 一つの空間の利用のために特定の時間を選択することがある。

\section{3 凟源を考虑したデザインの必要性}

以上のように、資源の概念を用いて行為を理解すれば、慣習的な空間

区画に基づく団地計画の問題を明確に把握することができる。 行為一資源の関係が考慮されない団地計画は、子どもの生活にとって 無意味であるとも言える。

居住地の外部空間が持つ多様な資源の影響力を考慮することは、 研究のみならず計画実務にも必要である。一つの外部空間が提供する 多様な資源の潜在力、子どもの多様な行為要求に対応できる外部空間 における資源の可変性は、計画実務で考慮すべき重要な観点となる。

\section{4 今後の研究課題}

本研究の主要な目的は、子どもの行為に止まらず、多様な居住者の 生活行為を説明するための理論を提示・実証することにある。資源に 関するより包括的な課題、例えば、利用者の行為に必要とされる資源と、 環境が提供する資源との整合性に関する問題、資源の詳細な定義と 類型化、資源が居住生活全般に与える影響などが、今後の研究課題で ある。

\section{注）}

注1)ベトナムでは、国状による調査の制約から、各調查対象地区について平日ま たは祝日のいずれかの調查を行い、韓国では、平日・祝日の2 日間の調查を行う こととした。両国とも、1日当たり、午後3〜4時、5〜6時の2回の巡回調査注4)を 実施した。

注2)子どもの集団による行為が観察される場合、集団の単位は、行為参加者と行 為関連者(Significant others) ${ }^{24)}$ から形成されるものと定義した。

注3）注2）で定義した集団で行われている行為を、1つの行為単位と見なし、その 内容を記録した。

注4)調查者が、事前に設定した観察経路に沿って移動し、移動時に観察される全 ての行為を詳細に記録寸る調查方法である。観察経路は、(1)経路上から調查対 象地区の全ての外部空間を見通せること、(2)観察対象空間が重複しないことを 条件に設定される。

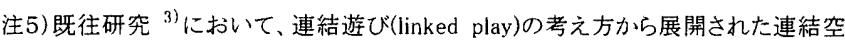
間(linked spaces)の概念。

注6) Lewin は知賞者の要求と価値観に基づき、対象物の誘発性が与えられるとし ている。従って、対象物の誘発性は知覚者の要求に対応して変化する。対象物 やそのアフォーダンスは変わらないにもかかわらず、ある人にとっての対象の有 用性は、人の要求の変化に従って変化する。また、Gibson は観察者がアフォ一 ダンスを認識するか否かは、彼の性質、経験、能力、要求によるとしている。人々 は 対象物や環境のアフォ一ダンスを学習し、それらを使うのが文化的に適当と されている状況を学ぶのである 25)。

\section{参孝文献}

1) Jeffrey D. Fisher, Paul A. Bell, Andrew Baum, Environmental psychology, Holt, Rinehart, and Winston, 1984

2) Michelson, W. : Man and his urban environment, A sociological orientation, Reading, MA, Addison-Wesley, 1976

3) Moore, G. : State of the art in play environment research and applications, In J.L. Frost \& S. Sunderlin (eds.), When children play, Wheaton MD, Association for Childhood Education Internation, 1985

4) Barker, R.: Ecological psychology, Concepts and methods for studying the environment of human behavior, Stanford, CA, Stanford University Press, 1968

5) Moos, R.:Assessment and impact of social climate, In P. McReynolds (ed.), Advances in psychological assessment, vol 3, Washington, DC, Jossey-Bass, 1975

6) Lawton, M. Powell: An ecological theory of aging applied to elder housing, Journal of architectural education 31 , no 1,6 10, 1977

7) Moore, R. \& Young, D:Childhood outdoors, Toward a social ecology of the landscape, In I. Altman \& J. Wohlwill (eds.), Human behavior and environment, Vol.3, Children and the environment, New York, Plenum, 1978.

8) Wohlwill, J. F. \& Heft, H. : The physical environment and the development of the child. In D., Stokols \& I. Altman (eds.), Handbook of environmental psychology. Vol.1, New York, John Wiley \& Sons., 1987

9）神田徳蔵：览童公園等戸外遊び場の利用者誘致特性に関寸る考察、戸外遊 び場施設の地域的整備に関寸る公園利用形態の研究その2、日本建築学会計 画系論文集、No.505、pp.97-104、1998.03

10）三輪律江、仙田満、矢田努:こどものあそび空間発生性に関する研究、日本 建築学会計画亲論文集、No.539、pp187-194、2001.01

11）粟原知子、熊澤栄二:「こともの遊び」にみる「生きた環境」の意味に関する研 究、日本建築学会㖕画系論文集、No.558、pp175-181、2002.08

12）閔丙昊:「ラビュタ」を捜して、子どものために居住団地の計画、世進社、 2001

13) Gibson, James J.: The theory of affordances, In R. Shaw \& J Bransford (eds.), Perceiving, acting, and knowing, Hillsdale, NJ, Lawrence Erlbaum Associates, 1977

14) Nicholson, S.: How not to cheat children, the theory of loose parts Landscape Architecture, 62(1), 30.34, 1971

15) Hart, R.A.: Children's experience of place, A developmental study, New York, Irvington Press, 1979

16) Cooper Marcus, C. \& Moore, R.: Children and their environments, A review of research Journal of Architectural Education, 29(4), pp 22-25, 1976

17) Hole, V. \& Miller, A.: Children's play on housing estates, A summary of two BRS studies, Architect's Journal, 25,pp 1529-1536,1966

18) Tuan, $\mathrm{Yi} \cdot \mathrm{Fu}:$ Space and place, The perspective of experience, University of Minnesota Press, 1977

19) Rapoport, Amos:Theory, culture, and housing, Housing, Theory and Society, 17(4),pp $145 \cdot 165,2000$

20) Taylor, A.F., Wiley, A., Kuo, F.E., \& Sullivan, W.C.: Growing up in the inner city, Green Spaces as places to grow. Environment and Behavior, $30(1), 3 \cdot 27,1998$

21）井門晃子、小林靖樹、野口考、加藤清子: 札幌市内の住宅地の性格と子供 の遊び環境に関する研究、北海道支部研究報告集、pp445-448、1996.03

22) $\mathrm{Abu} \cdot G$ hazzeh, T.:Children's use of the street as a Playground in $\mathrm{Abu} \cdot$ Nuseir, Jordan Environment and Behavior,30,pp 799.831, 1998

23）卡男一:居住地の外部空間の子ども遊び行為と建築計画要素に関寸る研究、 インドの居住地の事例について研究、覀洲大学、修士学位論文、1999

24) Zeisel, John: Inquiry by design, Tools for environment-behavior research, New York, Cambridge University Press, 1981

25) Lang, Jon T.: Creating architectural theory, the role of the behavioral sciences in environmental design, New York, Van Nostrand Reinhold Co. 1987 